\title{
Psychosocial stress and epigenetic aging
}

\section{Helena Palma-Gudiel ${ }^{a, b}$, Lourdes Fañanás ${ }^{a, b}$, Steve Horvath ${ }^{c, d}$, Anthony S. Zannas ${ }^{\mathrm{e}, \mathrm{f}, \mathrm{g}, \mathrm{h}, \mathrm{i}, *}$}

${ }^{a}$ Department of Evolutionary Biology, Ecology and Environmental Sciences, Faculty of Biology, University of Barcelona (UB), Barcelona, Spain

${ }^{\mathrm{b}}$ Centro de Investigación Biomédica en Red en Salud Mental (CIBERSAM), Madrid, Spain

${ }^{c}$ Department of Human Genetics, David Geffen School of Medicine, University of California Los Angeles, Los Angeles, CA, United States

${ }^{\mathrm{d}}$ Department of Biostatistics, Fielding School of Public Health, University of California Los Angeles, Los Angeles, CA, United States

${ }^{\mathrm{e}}$ Department of Psychiatry, University of North Carolina, Chapel Hill, NC, United States

fDepartment of Genetics, University of North Carolina, Chapel Hill, NC, United States

${ }^{g}$ Department of Psychiatry and Behavioral Sciences, Duke University Medical Center, Durham, NC,

United States

${ }^{\mathrm{h}}$ Institute for Trauma Recovery, University of North Carolina School of Medicine, Chapel Hill, NC,

United States

${ }^{\mathrm{i}}$ Neuroscience Curriculum, University of North Carolina, Chapel Hill, NC, United States

${ }^{*}$ Corresponding author: e-mail address: anthony_zannas@med.unc.edu

\section{Contents}

1. Chronological versus biological age 2

2. Epigenetic embedding of psychosocial stress 4

3. Exposure to life adversity accelerates epigenetic aging 10

4. Socioeconomic status and epigenetic aging 12

5. Developmental programming of epigenetic age at birth 13

6. Mechanistic insights of stress-mediated accelerated aging 15

References 16

\section{Abstract}

Aging is the single most important risk factor for diseases that are currently the leading causes of morbidity and mortality. However, there is considerable inter-individual variability in risk for aging-related disease, and studies suggest that biological age can be influenced by multiple factors, including exposure to psychosocial stress. Among markers of biological age that can be affected by stress, the present article focuses on the so-called measures of epigenetic aging: DNA methylation-based age predictors that are measured in a range of tissues, including the brain, and can predict lifespan and healthspan. We review evidence linking exposure to diverse types of psychosocial stress, including early-life stress, cumulative stressful experiences, and low socioeconomic status, with accelerated epigenetic aging as a putative mediator of the effects of psychosocial environment on health and disease. The chapter also discusses methodological 
differences that may contribute to discordant findings across studies to date and plausible mechanisms that may underlie the effects of stress on the aging epigenome. Future studies examining the effects of adversity on epigenetic and other indicators of biological weathering may provide important insights into the pathogenesis of aging-related disease states.

\section{Chronological versus biological age}

Aging is the single most important risk factor for several disease states that are currently the leading causes of morbidity and mortality (Niccoli \& Partridge, 2012). However, it is clear that health trajectories greatly differ among individuals of the same age, and biological age is thought to reflect weathering of the organism due to environmental exposures and disease processes. Efforts to better capture biological aging have led to the development of a wide range of biological measures, including telomere length, transcriptomic profiles, immunoglobulin G glycosylation patterns, blood serum metabolites, structural neuroimaging, and epigenomic profiles (Cole et al., 2018; Jylhävä, Pedersen, \& Hägg, 2017). Among these measures, this chapter will focus on epigenetic markers, which are the most robust predictors of age developed to date (Horvath \& Raj, 2018).

Epigenetics refers to any heritable chemical modification that affects gene expression without altering the genetic sequence itself. Epigenetic modifications are involved in several physiological processes such as the establishment and maintenance of cell lineages, X chromosome inactivation, and imprinting (Hackett \& Azim Surani, 2013; Lee \& Bartolomei, 2013). Furthermore, epigenetic mechanisms have been described to be involved in several complex disease states known to be influenced by gene-environment interactions $(\mathrm{GxE})$. One of the most widely studied epigenetic modifications is DNA methylation, which comprises the addition of a methyl group to a cytosine residue and in humans most commonly occurs in the context of cytosineguanine dinucleotides $(\mathrm{CpG})$. DNA methylation changes can influence gene expression (Siegfried \& Simon, 2010), thereby affecting gene and cell function.

Studies over the last years examining the role of age on epigenetic patterns have further led to the development of highly accurate epigenetic predictors of age or so-called epigenetic clocks. Table 1 summarizes the main characteristics of the four most widely used epigenetic clocks. Among the first ones and most widely used are those developed by Horvath (2013) and Hannum et al. (2013) in samples encompassing wide age ranges 
Table 1 Characteristics of DNA methylation-based predictors of age.

Horvath's

DNAm Age
PhenoAge

(Levine et

DNAm Age

\section{GrimAge}

(Lu et al.)

\begin{tabular}{lllll}
\hline CpG sites & 353 & 71 & 513 & 1030 \\
\hline Platform $^{a}$ & $27 \mathrm{~K}(450 \mathrm{~K})$ & $450 \mathrm{~K}$ & $\begin{array}{l}27 \mathrm{~K}(450 \mathrm{~K}, \\
\text { EPIC) }\end{array}$ & $450 \mathrm{~K}$ (EPIC) \\
\hline
\end{tabular}

\begin{tabular}{lllll}
\hline Training dataset $(\mathrm{n})$ & 3931 & 482 & 456 & 2356 \\
\hline Test dataset $(\mathrm{n})$ & 3211 & 174 & 9164 & 6935 \\
\hline $\begin{array}{l}\text { Correlation with } \\
\text { chronological age in } \\
\text { testing dataset }\end{array}$ & 0.96 & 0.91 & $0.62-0.89$ & 0.82 \\
\hline Accuracy & & & & \\
\hline
\end{tabular}

\begin{tabular}{lllll}
\hline Accuracy $^{\mathrm{b}}$ & 3.6 years & 4.9 years & NA & NA \\
\hline Tissue & $\begin{array}{l}\text { 51 different } \\
\text { tissues }\end{array}$ & Whole blood & Whole blood & Whole blood \\
\hline Age range & $0-101$ & $19-101$ & $21-100$ & $46-78$ \\
\hline
\end{tabular}

${ }^{a}$ DNA methylation array used for estimation; when some of the samples included in the study were assayed in larger platforms, they have been included inside parentheses to point out that actual CpG sites included in the regression model are solely the ones common to all platforms assayed.

${ }^{\mathrm{b}}$ Accuracy refers to median absolute error (MAE), i.e., the median absolute difference between predicted epigenetic age and observed or chronological age.

(up to 100 years old). Both these clocks are characterized by their high accuracy (0.91-0.96 correlation between estimated and observed age), but Horvath's clock predicts age more accurately than Hannum's in samples of younger individuals. Furthermore, Horvath's clock can be used in different tissues and cell types since it was trained in 51 different tissues, including blood, saliva and different brain areas, whereas Hannum's clock was developed using blood samples only.

Interestingly, the estimation of epigenetic age allows the calculation of the so-called epigenetic age acceleration, which reflects an increase in biological age in comparison to chronological age of the individual. This acceleration has been associated with several physiological processes, pathologies, and environmental factors, including puberty (Binder et al., 2018), menopause (Levine et al., 2016), Alzheimer's disease (Levine, Lu, Bennett, \& Horvath, 2015), and lifestyle (Quach et al., 2017), among several others (Gassen, Chrousos, Binder, \& Zannas, 2016; Horvath \& Raj, 2018). Exploration of the performance of the epigenetic clock in several tissues from the same subjects revealed that the cerebellum ages slowly 
when compared to other brain regions suggesting that different brain regions may be characterized by different rates of biological aging (Horvath et al., 2015).

Nonetheless, an epigenetic clock that is highly accurate in its age estimation might not be optimal for capturing inter-individual differences in epigenetic age acceleration. Thus, more recently developed clocks incorporate other parameters besides chronological age to better predict unfavorable outcomes. PhenoAge (Levine et al., 2018) integrates in the regression model a combination of clinical biomarkers such as blood concentration of albumin, creatinine, glucose, and C-reactive protein, and blood cell count. GrimAge (Lu et al., 2019) follows a similar approach by combining methylation levels at $\mathrm{CpG}$ sites which independently predict chronological age but also nine additional biomarkers including sex, leptin, cystatin $\mathrm{C}$, and smoking pack years. In contrast with Horvath's and Hannum's age predictors, PhenoAge and GrimAge aim to predict healthspan rather than lifespan.

\section{Epigenetic embedding of psychosocial stress}

Because acceleration of epigenetic age has been repeatedly associated with mortality (time-to-death) (Breitling et al., 2016; Chen, Marioni, et al., 2016; Marioni et al., 2015; Perna et al., 2016), it is of interest to elucidate which mechanisms might accelerate, or potentially decelerate, epigenetic aging. Studies on monozygotic twins (MZ) suggest that environmental factors can contribute to DNA methylation changes and cumulative epigenetic differences along the lifespan (Fraga et al., 2005). While several environmental factors, such as lifestyle parameters and communicable diseases, have been associated with epigenetic age acceleration (Kananen et al., 2015; Quach et al., 2017; Rosen et al., 2018), this chapter focuses on the relationship between psychosocial stress and epigenetic aging.

Psychosocial stress here refers to any situation or event that results in emotional discomfort and/or is experienced as threatening by the exposed subject. Childhood maltreatment, domestic violence, the death of a loved one, migration, and low socioeconomic position (SEP) are among the most studied stressors in the scientific literature. Experiencing any of those, particularly during the early stages of life (Marín, 2016), has been reliably associated with an increased vulnerability for complex disorders, including psychiatric phenotypes (Moya-Higueras et al., 2018; Teicher \& Samson, 2013). Exposure to psychosocial stressors such as adverse childhood experiences has been further associated with premature mortality; for example, subjects exposed to six or more childhood adversities were found to die 
on average 18.5 years earlier than subjects not exposed to adversity (Brown et al., 2009). Epigenetic mechanisms have been suggested as plausible mediators of this association (Gassen et al., 2016; Zannas et al., 2019).

Unlike biological parameters, exposure to psychosocial stress is more subjective and its assessment depends on memory recall. A recent meta-analysis demonstrated overall low agreement between prospective and retrospective measures of childhood maltreatment (Baldwin, Reuben, Newbury, \& Danese, 2019). In the same study, information collected through interviews rather than questionnaires appeared to be more reliable. Likewise, different types of stress are likely to differentially affect biological and clinical outcomes depending on the frequency, type, severity, and timing of the particular event (Miller, Chen, \& Zhou, 2007; Schalinski et al., 2016). Most studies assessing the effects of childhood trauma are conducted in adult populations by means of retrospective instruments; the Childhood Trauma Questionnaire (CTQ) is one of the most used throughout the literature, though it does not distinguish precise timing of the abuse (Bernstein et al., 1994).

Being born into an environment of low socioeconomic status (SES) is a risk factor for lifelong exposure to psychosocial stress (Lê-Scherban et al., 2018), since it has been associated with poorer parenting (Odgers et al., 2012) and increased exposure to stressful life events and violence (Lantz, House, Mero, \& Williams, 2005). Furthermore, the impact of low SES has been suggested to moderate the effects of exposure to childhood maltreatment, but the underlying mechanisms remain to be elucidated (Goldberg et al., 2013). In this regard, lower SES is reliably associated with worse general health, poorer cognitive performance, and higher proneness for psychopathology (Aartsen et al., 2019; de Mestral \& Stringhini, 2017; Lund et al., 2010).

Epigenetic mechanisms have been proposed to mediate the pernicious effects of the aforementioned environmental and sociodemographic risk factors. Genome-wide DNA methylation studies have revealed epigenetic patterns associated with socioeconomic status (Bush et al., 2018), institutionalization (Naumova et al., 2019), and altered stress reactivity after exposure to childhood maltreatment (Houtepen et al., 2016).

In this context, the aim of this chapter is to review evidence on whether psychosocial stress accelerates ticking of the epigenetic clock, potentially mediating known effects of stress exposure on health and disease outcomes. A comprehensive literature search yielded 15 scientific papers examining associations of DNA methylation-predicted age with exposure to psychosocial stress; their main findings are summarized in Table 2 and discussed in detail in the following sections. 
Table 2 Studies examining epigenetic age acceleration after exposure to stress or trauma.

\begin{tabular}{|c|c|c|c|c|c|c|c|c|}
\hline Study & $\begin{array}{l}\text { Sample } \\
\text { size }\end{array}$ & $\begin{array}{l}\text { Mean age } \\
\text { (SD; range) }\end{array}$ & $\begin{array}{l}\text { Female } \\
\text { sex (\%) }\end{array}$ & $\begin{array}{l}\text { Type of stress or trauma } \\
\text { (instrument) }\end{array}$ & $\begin{array}{l}\text { Clock } \\
\text { used }\end{array}$ & $\begin{array}{l}\text { Chronological/ } \\
\text { biological age } \\
\text { correlation (r) }\end{array}$ & Tissue assessed & Main findings \\
\hline Boks et al. (2015) & 96 & $\begin{array}{l}27.04 \\
(9.15)\end{array}$ & 0 & Traumatic stress (ETI) & Horvath & 0.99 & Whole blood & $\begin{array}{l}\text { Higher exposure to } \\
\text { (recent) combat trauma } \\
\text { during deployment-but } \\
\text { not childhood trauma- } \\
\text { was associated with } \\
\text { accelerated epigenetic } \\
\text { aging }\end{array}$ \\
\hline Zannas et al. (2015) & 393 & $\begin{array}{l}41.33 \\
(12.85) \\
39.5 \\
(14.14)\end{array}$ & $\begin{array}{l}70.7 \\
35.5\end{array}$ & $\begin{array}{l}\text { Childhood trauma } \\
\text { (CTQ) } \\
\text { Lifetime stress (SEQ) }\end{array}$ & Horvath & $\begin{array}{l}0.90 \\
0.94\end{array}$ & Whole blood & $\begin{array}{l}\text { Cumulative life stress- } \\
\text { but not current or } \\
\text { childhood stress-was } \\
\text { associated with accelerated } \\
\text { epigenetic aging }\end{array}$ \\
\hline $\begin{array}{l}\text { Brody, Yu, Chen, } \\
\text { Beach, and Miller } \\
\text { (2016) }\end{array}$ & 399 & 20 & 55 & $\begin{array}{l}\text { Parental depression } \\
(\text { CES-D) and harsh } \\
\text { parenting (4-item } \\
\text { personalized interview) }\end{array}$ & Horvath & NA & PBMC & $\begin{array}{l}\text { Parental depression (at age } \\
\text { 11) predicted higher } \\
\text { epigenetic age } \\
\text { acceleration at age } 20\end{array}$ \\
\hline $\begin{array}{l}\text { Brody, Miller, Yu, } \\
\text { Beach, and Chen } \\
\text { (2016) }\end{array}$ & 616 & $20-22$ & 60.2 & $\begin{array}{l}\text { Racial discrimination } \\
\text { during adolescence } \\
\text { (schedule of racist events) }\end{array}$ & Hannum & NA & PBMC & $\begin{array}{l}\text { In the absence of family } \\
\text { support, exposure to racial } \\
\text { discrimination is } \\
\text { associated with accelerated } \\
\text { epigenetic aging }\end{array}$ \\
\hline
\end{tabular}




\begin{tabular}{|c|c|c|c|c|c|c|c|c|}
\hline $\begin{array}{l}\text { Chen, Miller, et al. } \\
\text { (2016) }\end{array}$ & 330 & $19.3(0.67)$ & 53 & $\begin{array}{l}\text { SES (income, adequacy } \\
\text { of income, } \\
\text { unemployment, TANF } \\
\text { receipt, unmet material } \\
\text { needs, inability to make } \\
\text { ends meet) }\end{array}$ & $\begin{array}{l}\text { Horvath } \\
\text { Hannum }\end{array}$ & NA & PBMC & $\begin{array}{l}\text { Increased exposure to } \\
\text { economic hardship during } \\
\text { adolescence was associated } \\
\text { with accelerated } \\
\text { epigenetic aging in } \\
\text { subjects exposed to the } \\
\text { Great Recession }\end{array}$ \\
\hline $\begin{array}{l}\text { Simons et al. } \\
(2016)\end{array}$ & 100 & $48.5(9.2)$ & 100 & $\begin{array}{l}\text { SES (income and } \\
\text { financial pressure) } \\
\text { Childhood trauma } \\
\text { (personalized 5-item } \\
\text { interview) } \\
\text { Lifestyle (smoking, } \\
\text { alcohol intake, exercise, } \\
\text { diet, BMI) }\end{array}$ & Hannum & 0.82 & PBMC & $\begin{array}{l}\text { Lower income and higher } \\
\text { financial pressure were } \\
\text { associated with accelerated } \\
\text { epigenetic aging. } \\
\text { Neither childhood trauma } \\
\text { nor lifestyle were } \\
\text { associated with epigenetic } \\
\text { age. }\end{array}$ \\
\hline $\begin{array}{l}\text { Jovanovic et al. } \\
\text { (2017) }\end{array}$ & 93 & $\begin{array}{l}9.73(1.67 \\
6-13)\end{array}$ & 54.5 & $\begin{array}{l}\text { Exposure to violence } \\
\text { (VEX-R) }\end{array}$ & Horvath & 0.46 & Saliva & $\begin{array}{l}\text { Exposure to violence was } \\
\text { associated with accelerated } \\
\text { epigenetic aging; this } \\
\text { effect was driven by direct } \\
\text { exposure rather than } \\
\text { witnessing violence }\end{array}$ \\
\hline Fiorito et al. (2017) & 5111 & 57.3 & 48.0 & $\begin{array}{l}\text { SES (educational } \\
\text { attainment, occupational } \\
\text { position, income) }\end{array}$ & $\begin{array}{l}\text { Horvath } \\
\text { Hannum }\end{array}$ & $\begin{array}{l}0.73 \text { to } 0.80 \\
\text { depending on } \\
\text { clock }\end{array}$ & $\begin{array}{l}\text { Peripheral blood } \\
\text { (whole blood, } \\
\text { dried blood } \\
\text { spots and } \\
\text { PBMCs) }\end{array}$ & $\begin{array}{l}\text { Lower SES was associated } \\
\text { with accelerated } \\
\text { epigenetic age }\end{array}$ \\
\hline
\end{tabular}


Table 2 Studies examining epigenetic age acceleration after exposure to stress or trauma.-cont'd

\begin{tabular}{|c|c|c|c|c|c|c|c|c|}
\hline Study & $\begin{array}{l}\text { Sample } \\
\text { size }\end{array}$ & $\begin{array}{l}\text { Mean age } \\
\text { (SD; range) }\end{array}$ & $\begin{array}{l}\text { Female } \\
\text { sex (\%) }\end{array}$ & $\begin{array}{l}\text { Type of stress or trauma } \\
\text { (instrument) }\end{array}$ & $\begin{array}{l}\text { Clock } \\
\text { used }\end{array}$ & $\begin{array}{l}\text { Chronological/ } \\
\text { biological age } \\
\text { correlation (r) }\end{array}$ & Tissue assessed & Main findings \\
\hline Austin et al. (2018) & 335 & [15-55] & 54.8 & $\begin{array}{l}\text { Early-life SES (parental } \\
\text { occupational status) } \\
\text { Current SES (maximum } \\
\text { household occupational } \\
\text { status) }\end{array}$ & Horvath & 0.93 & Monocytes & $\begin{array}{l}\text { Low early-life SES (but } \\
\text { not current) was associated } \\
\text { with accelerated } \\
\text { epigenetic age }\end{array}$ \\
\hline Han et al. (2018) & 811 & $\begin{array}{l}41.5 \\
(12.26)\end{array}$ & 66.7 & $\begin{array}{l}\text { Childhood trauma } \\
\text { (NEMESIS-based } \\
\text { childhood trauma } \\
\text { interview) }\end{array}$ & $\begin{array}{l}\text { Tailored } \\
\text { for } \\
\text { MBD- } \\
\text { seq data }\end{array}$ & NA & Peripheral blood & $\begin{array}{l}\text { Childhood trauma was } \\
\text { associated with accelerated } \\
\text { epigenetic aging }\end{array}$ \\
\hline $\begin{array}{l}\text { Hughes et al. } \\
\text { (2018) }\end{array}$ & 1099 & $\begin{array}{l}58.4(14.9 ; \\
28-98)\end{array}$ & 57.6 & $\begin{array}{l}\text { SES (income, } \\
\text { employment, education, } \\
\text { childhood SES as parents' } \\
\text { social classification) }\end{array}$ & $\begin{array}{l}\text { Horvath } \\
\text { Hannum }\end{array}$ & $\begin{array}{l}0.90 \\
0.94\end{array}$ & Whole blood & $\begin{array}{l}\text { Social disadvantage during } \\
\text { childhood was associated } \\
\text { with accelerated } \\
\text { epigenetic age as measured } \\
\text { by both Horvath and } \\
\text { Hannum clocks. } \\
\text { No associations were } \\
\text { found for current SES }\end{array}$ \\
\hline Lawn et al. (2018) & $\begin{array}{l}989 \\
\text { (twice) } \\
+773\end{array}$ & $\begin{array}{l}28.65 \\
(5.54) \\
47.44 \\
(4.42) \\
53.44 \\
(0.16)\end{array}$ & 100 & $\begin{array}{l}\text { SES (father's and highest } \\
\text { current occupational } \\
\text { social class) } \\
\text { Psychosocial adversity } \\
\text { during childhood } \\
\text { (personalized } \\
\text { ALSPAC/NSHD } \\
\text { interview) }\end{array}$ & Horvath & $\begin{array}{l}0.45 \\
0.50 \\
0.12\end{array}$ & $\begin{array}{l}\text { Whole blood } \\
\text { Buccal cells }\end{array}$ & $\begin{array}{l}\text { Sexual abuse was } \\
\text { associated with accelerated } \\
\text { epigenetic aging in one of } \\
\text { the cohorts at both time } \\
\text { points. } \\
\text { No associations were } \\
\text { found for any other } \\
\text { psychosocial or } \\
\text { socioeconomic parameter }\end{array}$ \\
\hline
\end{tabular}




\begin{tabular}{|c|c|c|c|c|c|c|c|c|}
\hline $\begin{array}{l}\text { Sumner, Colich, } \\
\text { Uddin, Armstrong, } \\
\text { and McLaughlin } \\
(2019)\end{array}$ & 247 & $\begin{array}{l}12.7(2.6 ; \\
8-16)\end{array}$ & 47.8 & $\begin{array}{l}\text { Early-life adversity } \\
\text { (categorized as threat }^{\mathrm{a}} \\
\text { and deprivation }^{\mathrm{b}} \text { ) }\end{array}$ & Horvath & 0.62 & Saliva & $\begin{array}{l}\text { Exposure to threat-but } \\
\text { not to deprivation-was } \\
\text { associated with accelerated } \\
\text { epigenetic aging }\end{array}$ \\
\hline Wolf et al. (2018) & 2185 & $\begin{array}{l}40.2 \\
(18-89)\end{array}$ & 38.2 & $\begin{array}{l}\text { Childhood trauma } \\
\text { (CTQ/ETI) and lifetime } \\
\text { trauma (TLEQ, LEC, } \\
\text { TEI, self-report) }\end{array}$ & $\begin{array}{l}\text { Horvath } \\
\text { Hannum }\end{array}$ & $\begin{array}{l}0.87 \\
0.87\end{array}$ & Whole blood & $\begin{array}{l}\text { Childhood trauma but not } \\
\text { lifetime trauma was } \\
\text { associated with accelerated } \\
\text { epigenetic aging as } \\
\text { measured by Hannum's } \\
\text { but not Horvath's clock }\end{array}$ \\
\hline $\begin{array}{l}\text { McCrory et al. } \\
(2019)\end{array}$ & 490 & $\begin{array}{l}62.2(8.3 ; \\
50-87)\end{array}$ & 50.2 & $\begin{array}{l}\text { SES (social class } \\
\text { trajectory, education and } \\
\text { income) }\end{array}$ & $\begin{array}{l}\text { Horvath } \\
\text { Hannum } \\
\text { Levine }\end{array}$ & $\begin{array}{l}0.75 \\
0.75 \\
0.84\end{array}$ & Whole blood & $\begin{array}{l}\text { Epigenetic age } \\
\text { acceleration was not } \\
\text { associated with } \\
\text { socioeconomic position }\end{array}$ \\
\hline
\end{tabular}

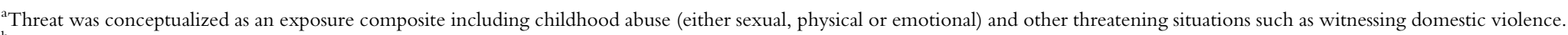
${ }^{\mathrm{b}}$ Deprivation was categorized as an exposure composite including childhood neglect (both emotional and physical), food insecurity and cognitive deprivation.

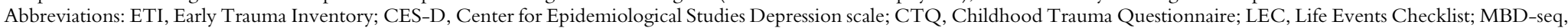

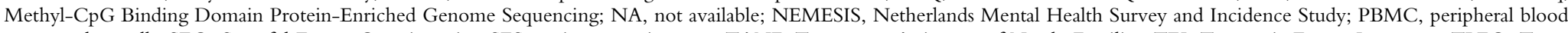

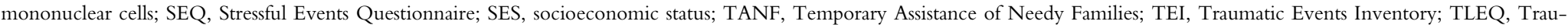
matic Life Events Questionnaire; VEX-R, Violence Exposure Scale for Children-Revised. 


\section{Exposure to life adversity accelerates epigenetic aging}

Ten out of 15 studies examined different types of childhood trauma and maltreatment. Of those, seven reported significant associations with accelerated epigenetic aging. Interestingly, the only two studies performed in children and adolescents (from 6 to 16 years) yielded positive results suggesting that proximal experiences correlate with epigenetic changes (Jovanovic et al., 2017; Sumner et al., 2019). Both studies highlighted that the nature of the stressor influenced its impact on biological age, since (i) direct exposure rather than witnessing violence and (ii) exposure to threatening rather than depriving environments, were the specific factors triggering age acceleration, respectively. Nevertheless, studies assessing epigenetic age in children and adolescents should be examined with caution as they include samples with narrow age range, whereby measures of epigenetic age only modestly correlate with chronological age (Jovanovic et al., 2017; Simpkin et al., 2017; Sumner et al., 2019). In an effort to address these limitations, two new DNA methylation-based clocks have been developed in independent samples of children and adolescents to more accurately estimate epigenetic age in these younger populations (Li et al., 2018; McEwen et al., 2019).

With regard to adult samples in which childhood adversity was assessed retrospectively, a study found that only sexual abuse was associated with age acceleration as opposed to other forms of early psychosocial adversity such as parental death, adoption, or neglect (Lawn et al., 2018), further highlighting the differential role of childhood trauma depending on stressor type. Although Lawn et al. did not find any association with parental mental illness, another study reported accelerated epigenetic age after exposure to parental depression at age 11 (Brody, Yu, et al., 2016). Discrepancies between studies could arise from sociodemographic differences between assessed samples, since Lawn's study was conducted in middle-aged Caucasian women while Brody et al. assessed African American youths. In the African American population, supportive parenting was further associated with buffering of the pernicious effects of exposure to racial discrimination during adolescence (Brody, Miller, et al., 2016).

The effect of childhood maltreatment on epigenetic age acceleration has been supported by a recent meta-analysis, which found that CTQ-measured maltreatment was associated with accelerated epigenetic aging assessed with 
the Hannum but not the Horvath clock (Wolf et al., 2018). Nevertheless, neither childhood trauma measured with Traumatic Life Events Questionnaire (TLEQ) nor lifetime trauma were associated with epigenetic age acceleration, and generalizability of these findings may be limited because the study was conducted in patients with post-traumatic stress disorder (PTSD). In line with these findings in PTSD, Han et al. reported a positive association between childhood trauma and accelerated epigenetic age in adult depressed subjects (Han et al., 2018). In contrast, three studies did not find significant associations between childhood maltreatment and epigenetic age; specifically, one of them was conducted in recently deployed soldiers (Boks et al., 2015), whereas the other two assessed the presence of childhood trauma in middle-aged African American participants of low socioeconomic status (Simons et al., 2016; Zannas et al., 2015).

These discordant findings could be in part explained by differences in the sociodemographic, clinical, and stressor characteristics across study cohorts. Exposure to acute stressors could induce transient epigenetic marks that are subject to change in the long-term and may thus not be detected if epigenetic aging is measured much later in life. The type and intensity of stress exposure may greatly influence its impact on subsequent epigenetic changes; for example, violent events are more likely to increase allostatic load. Likewise, adult subjects with current psychiatric diagnoses, such as major depression or PTSD, have likely been exposed to more adverse childhood environments (Scott, Smith, \& Ellis, 2010). Additionally, when adjusting for threatening events, experiences of deprivation seemed to delay pubertal development, suggesting that childhood adversities such as neglect or physical illnesses could decelerate rather than accelerate epigenetic aging. Because different types of childhood trauma greatly overlap in the general population (Vachon, Krueger, Rogosch, \& Cicchetti, 2015), it is challenging to disentangle the effects of co-occurring exposures.

Only three studies assessed later exposures to stressful life events, yielding discordant findings. While higher exposure to recent combat trauma (Boks et al., 2015) and higher cumulative lifetime stress (Zannas et al., 2015) were associated with accelerated epigenetic age, Wolf et al. (2018) reported no association between lifetime trauma and epigenetic age. Further longitudinal studies may help elucidate how life events occurring at different life stages differentially affect epigenetic aging and aging-related processes along the human lifespan. 


\section{Socioeconomic status and epigenetic aging}

Seven studies have explored whether lower socioeconomic status (SES) was associated with epigenetic age acceleration. Across these studies, current SES was defined based on (i) income, (ii) occupational position, and (iii) educational attainment. Early SES was defined based on parental occupational status during childhood. Studies assessing SES at both time points also considered SES trajectories as a function of whether SES had increased, decreased, or remained stable from childhood to adulthood.

While some of these studies found lower SES to be associated with accelerated epigenetic aging (Chen, Miller, et al., 2016; Fiorito et al., 2017; Simons et al., 2016), others did not find significant associations (Austin et al., 2018; Hughes et al., 2018; Lawn et al., 2018; McCrory et al., 2019). These discrepancies may result from differences in sample demographics and definition of SES across studies. Notably, Chen, Miller, et al. (2016) examined the youngest sample consisting of adolescents exposed to the Great Recession during their transition to adulthood. Simons et al. (2016) assessed African American women of very low-income settings, and the positive finding observed in this sample could in part be explained by reproductive factors, given that the number of pregnancies has been positively associated with maternal epigenetic aging (Ryan et al., 2018). Although Fiorito et al. (2017) assessed different indicators of SES, their main analysis focused on educational attainment using a standardized score adjusted for gender, age, ethnicity, and recruitment center rather than a direct measure such as years of education. Indeed, higher educational attainment has been repeatedly associated with lower epigenetic aging (Levine et al., 2018; Lu et al., 2019; Quach et al., 2017). In contrast, studies reporting lack of association between SES and epigenetic aging are characterized by the use of a dichotomous occupational status as a proxy for SES (Austin et al., 2018; Hughes et al., 2018; Lawn et al., 2018; McCrory et al., 2019). Lastly, although McCrory et al. (2019) found no epigenetic age acceleration with neither childhood nor adulthood low SES, they found an association with higher allostatic load as measured with a multi-modal marker derived from physiological measurements.

Parental income and occupational position during childhood were used as proxies of early SES in some studies (Austin et al., 2018; Hughes et al., 2018; Lawn et al., 2018). Two of these studies point to the preeminent role of early SES as a driver of accelerated epigenetic age. These results are in line 
with prior evidence suggesting that childhood is a critical developmental window for the programming of risk for complex disorders (Pervanidou \& Chrousos, 2018).

An alternative approach is to study SES trajectories from childhood to adulthood. Stably high economic hardship - stably low SES - and upward mobility from low to high SES were both associated with epigenetic age acceleration when compared with stably high SES and downward mobility (Austin et al., 2018; Chen, Miller, et al., 2016). Such findings highlight that economic resources available during childhood may influence the ticking rate of the epigenetic clock. Notwithstanding, lack of difference in epigenetic aging across SES trajectories has also been reported (McCrory et al., 2019). The fact that upward mobility did not positively influence epigenetic aging is in line with exploratory studies suggesting that resilience after trauma is associated with a lasting epigenetic footprint. Specifically, higher self-control in low-SES youth predicted lower rates of aggressive behavior and substance abuse but was associated with accelerated epigenetic age (Miller, Yu, Chen, \& Brody, 2015). Likewise, in a sample of war veterans with PTSD, higher resilience scores-better coping strategies-were also associated with accelerated epigenetic age (Mehta et al., 2018). Collectively, these findings suggest a biological state of accelerated aging and higher allostatic load in subjects that successfully overcome adversities.

Demographic characteristics other than SES should also be considered as potential confounders. A recent study explored how gender and ethnicity can influence the ticking rate of the epigenetic clock revealing men age faster than women and Caucasian, Hispanic, Amerindian and African American subjects show distinctive epigenetic aging patterns (Horvath et al., 2016).

\section{Developmental programming of epigenetic age at birth}

Interestingly, two additional DNA methylation-based epigenetic clocks were developed for the estimation of gestational age (GA) at birth (Bohlin et al., 2016; Knight et al., 2016; see Table 3 for further details). These clocks allow researchers to explore which prenatal risk factors might be influencing developmental maturity of newborns.

Intuitively, it could be hypothesized that higher prenatal stress would be associated with accelerated epigenetic GA; however, findings reported so far suggest an opposite direction of effects. Specifically, gestational diabetes in a 
Table 3 Characteristics of DNA methylation-based predictors of gestational age.

Knight's clock for

gestational age

\begin{tabular}{lll}
\hline CpG sites & 148 & $96 / 58$ \\
\hline Platform $^{\mathrm{a}}$ & $27 \mathrm{~K}(450 \mathrm{~K})$ & $450 \mathrm{~K}$ \\
\hline
\end{tabular}

Training dataset (n) 207

Test dataset (n) 1135

$\begin{array}{lll}\text { Correlation with } & 0.91 & 0.81 / 0.7\end{array}$

chronological age

\begin{tabular}{lll}
\hline Accuracy $^{\mathrm{b}}$ & 1.24 weeks & $12.5 / 14.9$ days \\
\hline Tissue & Cord blood & Cord blood \\
\hline Age range & $24-42$ gestational weeks & $\overline{\mathrm{x}}=40$ gestational weeks \\
\hline
\end{tabular}

${ }^{a}$ DNA methylation array used for estimation; when some of the samples included in the study were assayed in larger platforms, they have been included inside parentheses to point out that actual CpG sites included in the regression model are solely the ones common to all platforms assayed.

${ }^{\mathrm{b}}$ Accuracy refers to median absolute error (MAE), i.e., the median absolute difference between predicted epigenetic age and observed or chronological age.

previous pregnancy, Sjögren's syndrome, maternal history of depression before pregnancy, antenatal depressive symptoms, and lower cerebroplacental ratio during pregnancy (a proxy for prenatal hypoxia and/or placental resistance) were all associated with epigenetic GA deceleration (Girchenko et al., 2017; Palma-Gudiel et al., 2019; Suarez et al., 2018). Thus, exposure to stress during prenatal stages of life is associated with decreased biological age, which could be conceptualized as a marker of developmental immaturity at birth. Knight et al. (2018) further tested the clinical relevance of epigenetic GA deceleration at birth in terms of perinatal health revealing an increased need of neonatal interventions and heightened risk of bronchopulmonary dysplasia. Conversely, excessive maternal weight and obesity before pregnancy were associated with accelerated epigenetic GA at birth (Khouja et al., 2018), suggesting that these conditions hasten fetal development. Girchenko et al. (2017) also found maternal pre-eclampsia, maternal age over 40 years at delivery, and fetal demise in a previous pregnancy to be associated with accelerated epigenetic GA.

Taken together, these results suggest a dual nature for the effects of stress on aging-related processes, whereby depriving environments may give rise to delayed development - and thus decelerated epigenetic age-whereas threatening events may be associated with heightened allostatic load and 
accelerated epigenetic aging. Notably, the rate of change of epigenetic aging is faster during development (Horvath \& Raj, 2018), and while age acceleration might be beneficial during the early stages of life-promoting survival and growth - it may be also associated with later premature mortality. Large epidemiological and longitudinal studies should be conducted to explore how the rate of biological aging may impact developmental programming. Furthermore, alternative measures of biological aging, such as neuroimaging-derived brain age, have revealed the positive association between prenatal undernutrition and premature brain aging (Franke, Gaser, Roseboom, Schwab, \& de Rooij, 2018). These results highlight the interest of exploring simultaneously different markers of biological age, as different organs are known to have independent age rates in the same individuals; thus, there could be tissue-specific effects of epigenetic age predictors, e.g., brain epigenetic aging better informs about neurodegenerative processes (Levine et al., 2015) while blood epigenetic age better reflects cardiovascular risk (Huang et al., 2019).

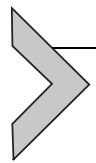

\section{Mechanistic insights of stress-mediated accelerated aging}

Throughout evolution, living beings have developed diverse strategies to cope with stress. In vertebrates and humans, the hypothalamic-pituitaryadrenal (HPA) axis culminates with cortisol secretion in the bloodstream upon exposure to stressful stimuli. As a lipophilic molecule, cortisol diffuses through the cell membrane and reaches the cytoplasm where it can bind to the glucocorticoid receptor (GR). Once bound to cortisol, the GR translocates to the cell nucleus to regulate gene expression. The key role played by the GR in the stress response has prompted abundant research on how stress exposure could lead to altered DNA methylation of the NR3C1 gene encoding this receptor (Palma-Gudiel, Córdova-Palomera, Leza, \& Fañanás, 2015). Specifically, the GR exerts its actions through binding to so-called glucocorticoid responsive elements (GREs) (Palma-Gudiel et al., 2018). Notably, a large proportion of $\mathrm{CpG}$ sites comprising the Horvath's epigenetic clock co-localize with GREs and are susceptible to glucocorticoid exposure, suggesting that circulating glucocorticoids could mediate the effects of psychosocial stress on epigenetic aging (Zannas et al., 2015).

Beyond such composite epigenomic effects, stress may also impart epigenetic changes at genomic loci relevant for aging-related phenomena. 
Such a locus is FKBP5, the gene encoding a stress-responsive molecule implicated in regulation of HPA axis function and stress responses. Previously, FKBP5 DNA methylation was shown to partially mediate the known association between exposure to childhood trauma and later development of PTSD (Klengel et al., 2013). More recently, epigenetic upregulation of FKBP5 was found to result from the synergistic effects of aging and stress and to contribute to increased inflammation and cardiovascular risk (Zannas et al., 2019). These findings suggest that epigenetic regulation of FKBP5, and likely other stress-responsive molecules, may in part mediate the impact of psychosocial stress on aging-related disease states.

Elucidating the mechanisms through which stress exposure contributes to accelerated epigenetic aging may enhance our ability to prevent the high mortality and morbidity rates associated with adverse environments. Predictions based on DNA methylation-based markers may also inform which interventions have the potential to buffer the pernicious effects of stress at the molecular level. Evidence to date suggests that early-life stress can be deleterious, but longitudinal studies are needed to clarify the dynamics and putative stability or reversibility of the effects on epigenetic aging. The advent of novel measures of epigenetic aging aimed at predicting not only lifespan but also healthspan opens new avenues for research in the field. Future studies examining the effects of adversity on these indicators of biological weathering may provide novel insights into aging-related phenomena. Postmortem brain analyses are also needed to understand how different kinds of stress can accelerate epigenetic aging not only in peripheral tissues such as blood or saliva but also in different brain areas as it seems to be associated with several neurodegenerative conditions.

\section{References}

Aartsen, M. J., Cheval, B., Sieber, S., Van der Linden, B. W., Gabriel, R., Courvoisier, D. S., et al. (2019). Advantaged socioeconomic conditions in childhood are associated with higher cognitive functioning but stronger cognitive decline in older age. Proceedings of the National Academy of Sciences, 116(12), 5478 LP-5486. https://doi.org/10.1073/ pnas. 1807679116.

Austin, M. K., Chen, E., Ross, K. M., McEwen, L. M., Maclsaac, J. L., Kobor, M. S., et al. (2018). Early-life socioeconomic disadvantage, not current, predicts accelerated epigenetic aging of monocytes. Psychoneuroendocrinology, 97(January), 131-134. https://doi. org/10.1016/j.psyneuen.2018.07.007.

Baldwin, J. R., Reuben, A., Newbury, J. B., \& Danese, A. (2019). Agreement between prospective and retrospective measures of childhood maltreatment: A systematic review and meta-analysis. JAMA Psychiatry, 76(6), 584-593. https://doi.org/10.1001/ jamapsychiatry.2019.0097. 
Bernstein, D. P., Fink, L., Handelsman, L., Foote, J., Lovejoy, M., Wenzel, K., et al. (1994). Initial reliability and validity of a new retrospective measure of child abuse and neglect. American Journal of Psychiatry, 151(8), 1132-1136. https://doi.org/10.1176/ajp.151.8.1132.

Binder, A. M., Corvalan, C., Mericq, V., Pereira, A., Santos, J. L., Horvath, S., et al. (2018). Faster ticking rate of the epigenetic clock is associated with faster pubertal development in girls. Epigenetics, 13(1), 85-94. https://doi.org/10.1080/15592294.2017.1414127.

Bohlin, J., Håberg, S. E., Magnus, P., Reese, S. E., Gjessing, H. K., Magnus, M. C., et al. (2016). Prediction of gestational age based on genome-wide differentially methylated regions. Genome Biology, 17(1), 207. https://doi.org/10.1186/s13059-016-1063-4.

Boks, M. P., van Mierlo, H. C., Rutten, B. P. F., Radstake, T. R. D. J., De Witte, L., Geuze, E., et al. (2015). Longitudinal changes of telomere length and epigenetic age related to traumatic stress and post-traumatic stress disorder. Psychoneuroendocrinology, 51, 506-512. https://doi.org/10.1016/j.psyneuen.2014.07.011.

Breitling, L. P., Saum, K.-U., Perna, L., Schöttker, B., Holleczek, B., \& Brenner, H. (2016). Frailty is associated with the epigenetic clock but not with telomere length in a German cohort. Clinical Epigenetics, 8(1), 21. https://doi.org/10.1186/s13148-016-0186-5.

Brody, G. H., Miller, G. E., Yu, T., Beach, S. R. H., \& Chen, E. (2016). Supportive family environments ameliorate the link between racial discrimination and epigenetic aging: A replication across two longitudinal cohorts. Psychological Science, 27(4), 530-541. https://doi.org/10.1177/0956797615626703.

Brody, G. H., Yu, T., Chen, E., Beach, S. R. H., \& Miller, G. E. (2016). Family-centered prevention ameliorates the longitudinal association between risky family processes and epigenetic aging. Journal of Child Psychology and Psychiatry, and Allied Disciplines, 57(5), 566-574. https://doi.org/10.1111/jcpp.12495.

Brown, D. W., Anda, R. F., Tiemeier, H., Felitti, V. J., Edwards, V. J., Croft, J. B., et al. (2009). Adverse childhood experiences and the risk of premature mortality. American Journal of Preventive Medicine, 37(5), 389-396. https://doi.org/10.1016/j.amepre.2009. 06.021.

Bush, N. R., Edgar, R. D., Park, M., MacIsaac, J. L., McEwen, L. M., Adler, N. E., et al. (2018). The biological embedding of early-life socioeconomic status and family adversity in children's genome-wide DNA methylation. Epigenomics, 10(11), 1445-1461. https:// doi.org/10.2217/epi-2018-0042.

Chen, B. H., Marioni, R. E., Colicino, E., Peters, M. J., Ward-Caviness, C. K., Tsai, P. C., et al. (2016). DNA methylation-based measures of biological age: Meta-analysis predicting time to death. Aging, 8, 1844-1865. https://doi.org/10.18632/aging.101020.

Chen, E., Miller, G. E., Yu, T., \& Brody, G. H. (2016). The Great Recession and health risks in African American youth. Brain, Behavior, and Immunity, 53, 234-241. https://doi.org/ 10.1016/j.bbi.2015.12.015.

Cole, J. H., Ritchie, S. J., Bastin, M. E., Valdés Hernández, M. C., Muñoz Maniega, S., Royle, N., et al. (2018). Brain age predicts mortality. Molecular Psychiatry, 23(5), 1385-1392. https://doi.org/10.1038/mp.2017.62.

de Mestral, C., \& Stringhini, S. (2017). Socioeconomic status and cardiovascular disease: An update. Current Cardiology Reports, 19(11), 115. https://doi.org/10.1007/s11886-0170917-z.

Fiorito, G., Polidoro, S., Dugué, P. A., Kivimaki, M., Ponzi, E., Matullo, G., et al. (2017). Social adversity and epigenetic aging: A multi-cohort study on socioeconomic differences in peripheral blood DNA methylation. Scientific Reports, 7(1), 1-12. https://doi. org/10.1038/s41598-017-16391-5.

Fraga, M. F., Ballestar, E., Paz, M. F., Ropero, S., Setien, F., Ballestar, M. L., et al. (2005). Epigenetic differences arise during the lifetime of monozygotic twins. Proceedings of the National Academy of Sciences of the United States of America, 102(30), 10604-10609. https://doi.org/10.1073/pnas.0500398102. 
Franke, K., Gaser, C., Roseboom, T. J., Schwab, M., \& de Rooij, S. R. (2018). Premature brain aging in humans exposed to maternal nutrient restriction during early gestation. NeuroImage, 173, 460-471. https://doi.org/10.1016/j.neuroimage.2017.10.047.

Gassen, N. C., Chrousos, G. P., Binder, E. B., \& Zannas, A. S. (2016). Life stress, glucocorticoid signaling, and the aging epigenome: Implications for aging-related diseases. Neuroscience and Biobehavioral Reviews, 74(Pt. B), 356-365. https://doi.org/10.1016/j. neubiorev.2016.06.003.

Girchenko, P., Lahti, J., Czamara, D., Knight, A. K., Jones, M. J., Suarez, A., et al. (2017). Associations between maternal risk factors of adverse pregnancy and birth outcomes and the offspring epigenetic clock of gestational age at birth. Clinical Epigenetics, 9(1), 1-14. https://doi.org/10.1186/s13148-017-0349-z.

Goldberg, X., Alemany, S., Fatjó-Vilas, M., González-Ortega, I., González-Pinto, A., Cuesta, M. J., et al. (2013). Twin-based study of the complex interplay between childhood maltreatment, socioeconomic status and adult memory. European Archives of Psychiatry and Clinical Neuroscience, 263(5), 435-440. https://doi.org/10.1007/s00406012-0382-z.

Hackett, J. A., \& Azim Surani, M. (2013). DNA methylation dynamics during the mammalian life cycle. Philosophical Transactions of the Royal Society, B: Biological Sciences, 368(1609), 1-8. https://doi.org/10.1098/rstb.2011.0328.

Han, L. K. M., Aghajani, M., Clark, S. L., Chan, R. F., Hattab, M. W., Shabalin, A. A., et al. (2018). Epigenetic aging in major depressive disorder. American Journal of Psychiatry, 175(8), 774-782. https://doi.org/10.1176/appi.ajp.2018.17060595.

Hannum, G., Guinney, J., Zhao, L., Zhang, L., Hughes, G., Sadda, S. V., et al. (2013). Genome-wide methylation profiles reveal quantitative views of human aging rates. Molecular Cell, 49(2), 359-367. https://doi.org/10.1016/j.molcel.2012.10.016.

Horvath, S. (2013). DNA methylation age of human tissues and cell types. Genome Biology, 14(10), R115. https://doi.org/10.1186/gb-2013-14-10-r115.

Horvath, S., Gurven, M., Levine, M. E., Trumble, B. C., Kaplan, H., Allayee, H., et al. (2016). An epigenetic clock analysis of race/ethnicity, sex, and coronary heart disease. Genome Biology, 17(1), 171. https://doi.org/10.1186/s13059-016-1030-0.

Horvath, S., Mah, V., Lu, A. T., Woo, J. S., Choi, O. W., Jasinska, A. J., et al. (2015). The cerebellum ages slowly according to the epigenetic clock. Aging, 7(5), 294-305.

Horvath, S., \& Raj, K. (2018). DNA methylation-based biomarkers and the epigenetic clock theory of ageing. Nature Reviews Genetics, 19(6), 371-384. https://doi.org/10.1038/ s41576-018-0004-3.

Houtepen, L. C., Vinkers, C. H., Carrillo-Roa, T., Hiemstra, M., van Lier, P. A., Meeus, W., et al. (2016). Genome-wide DNA methylation levels and altered cortisol stress reactivity following childhood trauma in humans. Nature Communications, 7, 10967. Retrieved from https://doi.org/10.1038/ncomms10967.

Huang, R.-C., Lillycrop, K. A., Beilin, L. J., Godfrey, K. M., Anderson, D., Mori, T. A., et al. (2019). Epigenetic age acceleration in adolescence associates with BMI, inflammation, and risk score for middle age cardiovascular disease. The Journal of Clinical Endocrinology \& Metabolism, 104(7), 3012-3024. https://doi.org/10.1210/jc.201802076.

Hughes, A., Smart, M., Gorrie-Stone, T., Hannon, E., Mill, J., Bao, Y., et al. (2018). Socioeconomic position and DNA methylation age acceleration across the life course. American Journal of Epidemiology, 187(11), 2346-2354. https://doi.org/10.1093/aje/ kwy155.

Jovanovic, T., Vance, L. A., Cross, D., Knight, A. K., Kilaru, V., Michopoulos, V., et al. (2017). Exposure to violence accelerates epigenetic aging in children. Scientific Reports, 7(1), 1-7. https://doi.org/10.1038/s41598-017-09235-9. 
Jylhävä, J., Pedersen, N. L., \& Hägg, S. (2017). Biological age predictors. eBioMedicine, 21, 29-36. https://doi.org/10.1016/j.ebiom.2017.03.046.

Kananen, L., Nevalainen, T., Jylhävä, J., Marttila, S., Hervonen, A., Jylhä, M., et al. (2015). Cytomegalovirus infection accelerates epigenetic aging. Experimental Gerontology, 72, 227-229. https://doi.org/10.1016/j.exger.2015.10.008.

Khouja, J. N., Simpkin, A. J., O’Keeffe, L. M., Wade, K. H., Houtepen, L. C., Relton, C. L., et al. (2018). Epigenetic gestational age acceleration: A prospective cohort study investigating associations with familial, sociodemographic and birth characteristics. Clinical Epigenetics, 10(1), 86. https://doi.org/10.1186/s13148-018-0520-1.

Klengel, T., Mehta, D., Anacker, C., Rex-Haffner, M., Pruessner, J. C., Pariante, C. M., et al. (2013). Allele-specific FKBP5 DNA demethylation mediates gene-childhood trauma interactions. Nature Neuroscience, 16(1), 33-41. https://doi.org/10.1038/ nn.3275.

Knight, A. K., Craig, J. M., Theda, C., Bækvad-Hansen, M., Bybjerg-Grauholm, J., Hansen, C. S., et al. (2016). An epigenetic clock for gestational age at birth based on blood methylation data. Genome Biology, 17(1), 1-11. https://doi.org/10.1186/ s13059-016-1068-z.

Knight, A. K., Smith, A. K., Conneely, K. N., Dalach, P., Loke, Y. J., Cheong, J. L., et al. (2018). Relationship between epigenetic maturity and respiratory morbidity in preterm infants. The Journal of Pediatrics, 198, 168-173.e2. https://doi.org/10.1016/j.jpeds. 2018.02.074.

Lantz, P. M., House, J. S., Mero, R. P., \& Williams, D. R. (2005). Stress, life events, and socioeconomic disparities in health: Results from the Americans' changing lives study. Journal of Health and Social Behavior, 46(3), 274-288. https://doi.org/10.1177/ 002214650504600305.

Lawn, R. B., Anderson, E. L., Suderman, M., Simpkin, A. J., Gaunt, T. R., Teschendorff, A. E., et al. (2018). Psychosocial adversity and socioeconomic position during childhood and epigenetic age: Analysis of two prospective cohort studies. Human Molecular Genetics, 27(7), 1301-1308. https://doi.org/10.1093/hmg/ddy036.

Lee, J. T., \& Bartolomei, M. S. (2013). X-inactivation, imprinting, and long noncoding RNAs in health and disease. Cell, 152(6), 1308-1323. https://doi.org/10.1016/j. cell.2013.02.016.

Lê-Scherban, F., Brenner, A. B., Hicken, M. T., Needham, B. L., Seeman, T., Sloan, R. P., et al. (2018). Child and adult socioeconomic status and the cortisol response to acute stress: Evidence from the multi-ethnic study of atherosclerosis. Psychosomatic Medicine, 80(2), 184-192. Retrieved from https://journals.lww.com/psychosomaticmedicine/ Fulltext/2018/02000/Child_and_Adult_Socioeconomic_Status_and_the.8.aspx.

Levine, M. E., Lu, A. T., Bennett, D. A., \& Horvath, S. (2015). Epigenetic age of the prefrontal cortex is associated with neuritic plaques, amyloid load, and Alzheimer's disease related cognitive functioning. Aging, 7(12), 1198-1211. https://doi.org/10.18632/ aging.100864.

Levine, M. E., Lu, A. T., Chen, B. H., Hernandez, D. G., Singleton, A. B., Ferrucci, L., et al. (2016). Menopause accelerates biological aging. Proceedings of the National Academy of Sciences of the United States of America, 113(33), 9327-9332. https://doi.org/10.1073/ pnas.1604558113.

Levine, M. E., Lu, A. T., Quach, A., Chen, B. H., Assimes, T. L., Bandinelli, S., et al. (2018). An epigenetic biomarker of aging for lifespan and healthspan. Aging, 10(4), 573-591. https://doi.org/10.18632/aging.101414.

Li, C., Gao, W., Gao, Y., Yu, C., Lv, J., Lv, R., et al. (2018). Age prediction of children and adolescents aged 6-17 years: An epigenome-wide analysis of DNA methylation. Aging, 10(5), 1015-1026. https://doi.org/10.18632/aging.101445. 
Lu, A. T., Quach, A., Wilson, J. G., Reiner, A. P., Aviv, A., Raj, K., et al. (2019). DNA methylation GrimAge strongly predicts lifespan and healthspan. Aging, 11(2), 303-327. https://doi.org/10.18632/aging.101684.

Lund, C., Breen, A., Flisher, A. J., Kakuma, R., Corrigall, J., Joska, J. A., et al. (2010). Poverty and common mental disorders in low and middle income countries: A systematic review. Social Science \& Medicine, 71(3), 517-528. https://doi.org/10.1016/ j.socscimed.2010.04.027.

Marín, O. (2016). Developmental timing and critical windows for the treatment of psychiatric disorders. Nature Medicine, 22(11), 1229-1238. https://doi.org/10.1038/ nm. 4225 .

Marioni, R. E., Shah, S., McRae, A. F., Chen, B. H., Colicino, E., Harris, S. E., et al. (2015). DNA methylation age of blood predicts all-cause mortality in later life. Genome Biology, 16(1), 25. https://doi.org/10.1186/s13059-015-0584-6.

McCrory, C., Fiorito, G., Ni Cheallaigh, C., Polidoro, S., Karisola, P., Alenius, H., et al. (2019). How does socio-economic position (SEP) get biologically embedded? A comparison of allostatic load and the epigenetic clock(s). Psychoneuroendocrinology, 104, 64-73. https://doi.org/10.1016/j.psyneuen.2019.02.018 [October 2018].

McEwen, L. M., O’Donnell, K. J., McGill, M. G., Edgar, R. D., Jones, M. J., MacIsaac, J. L., et al. (2019). The PedBE clock accurately estimates DNA methylation age in pediatric buccal cells. Proceedings of the National Academy of Sciences of the United States of America. https://doi.org/10.1073/pnas.1820843116.

Mehta, D., Bruenig, D., Lawford, B., Harvey, W., Carrillo-Roa, T., Morris, C. P., et al. (2018). Accelerated DNA methylation aging and increased resilience in veterans: The biological cost for soldiering on. Neurobiology of Stress, 8, 112-119. https://doi.org/ 10.1016/j.ynstr.2018.04.001 [November 2017].

Miller, G. E., Chen, E., \& Zhou, E. S. (2007). If it goes up, must it come down? Chronic stress and the hypothalamic-pituitary-adrenocortical axis in humans. Psychological Bulletin, 133(1), 25-45. https://doi.org/10.1037/0033-2909.133.1.25.

Miller, G. E., Yu, T., Chen, E., \& Brody, G. H. (2015). Self-control forecasts better psychosocial outcomes but faster epigenetic aging in low-SES youth. Proceedings of the National Academy of Sciences of the United States of America, 112(33), 10325-10330. https://doi.org/ 10.1073/pnas. 1505063112.

Moya-Higueras, J., Cuevas, A., Marques-Feixa, L., Mezquita, L., Mayoral, M., Fañanás, L., et al. (2018). Recent stressful life events (SLE) and adolescent mental health: Initial validation of the LEIA, a new checklist for SLE assessment according to their severity, interpersonal, and dependent nature. Assessment. 1073191118817648. https://doi.org/ 10.1177/1073191118817648.

Naumova, O. Y., Rychkov, S. Y., Kornilov, S. A., Odintsova, V. V., Anikina, V. O., Solodunova, M. Y., et al. (2019). Effects of early social deprivation on epigenetic statuses and adaptive behavior of young children: A study based on a cohort of institutionalized infants and toddlers. PLoS One, 14(3), e0214285. Retrieved from https://doi.org/10. 1371/journal.pone.0214285.

Niccoli, T., \& Partridge, L. (2012). Ageing as a risk factor for disease. Current Biology, 22(17), R741-R752. https://doi.org/10.1016/j.cub.2012.07.024.

Odgers, C. L., Caspi, A., Russell, M. A., Sampson, R. J., Arseneault, L., \& Moffitt, T. E. (2012). Supportive parenting mediates neighborhood socioeconomic disparities in children's antisocial behavior from ages 5 to 12. Development and Psychopathology, 24, 705-721. https://doi.org/10.1017/s0954579412000326.

Palma-Gudiel, H., Córdova-Palomera, A., Leza, J. C., \& Fañanás, L. (2015). Glucocorticoid receptor gene (NR3C1) methylation processes as mediators of early adversity in stress-related disorders causality: A critical review. Neuroscience and Biobehavioral Reviews, 55, 520-535. https://doi.org/10.1016/j.neubiorev.2015.05.016. 
Palma-Gudiel, H., Córdova-Palomera, A., Tornador, C., Falcón, C., Bargalló, N., Deco, G., et al. (2018). Increased methylation at an unexplored glucocorticoid responsive element within exon $1 \mathrm{D}$ of NR3C1 gene is related to anxious-depressive disorders and decreased hippocampal connectivity. European Neuropsychopharmacology, 28(5), 579-588. https:// doi.org/10.1016/j.euroneuro.2018.03.015.

Palma-Gudiel, H., Eixarch, E., Crispi, F., Morán, S., Zannas, A. S., \& Fañanás, L. (2019). Prenatal adverse environment is associated with epigenetic age deceleration at birth and hypomethylation at the hypoxia-responsive EP300 gene. Clinical Epigenetics, 11(1), 73. https://doi.org/10.1186/s13148-019-0674-5.

Perna, L., Zhang, Y., Mons, U., Holleczek, B., Saum, K.-U., \& Brenner, H. (2016). Epigenetic age acceleration predicts cancer, cardiovascular, and all-cause mortality in a German case cohort. Clinical Epigenetics, 8(1), 64. https://doi.org/10.1186/s13148016-0228-z.

Pervanidou, P., \& Chrousos, G. P. (2018). Early-life stress: From neuroendocrine mechanisms to stress-related disorders. Hormone Research in Padiatrics, 89(5), 372-379. https://doi.org/10.1159/000488468.

Quach, A., Levine, M. E., Tanaka, T., Lu, A. T., Chen, B. H., Ferrucci, L., et al. (2017). Epigenetic clock analysis of diet, exercise, education, and lifestyle factors. Aging, 9(2), 419-446. https://doi.org/10.18632/aging.101168.

Rosen, A. D., Robertson, K. D., Hlady, R. A., Muench, C., Lee, J., Philibert, R., et al. (2018). DNA methylation age is accelerated in alcohol dependence. Translational Psychiatry, 8(1), 182. https://doi.org/10.1038/s41398-018-0233-4.

Ryan, C. P., Hayes, M. G., Lee, N. R., McDade, T. W., Jones, M. J., Kobor, M. S., et al. (2018). Reproduction predicts shorter telomeres and epigenetic age acceleration among young adult women. Scientific Reports, 8(1), 1-9. https://doi.org/10.1038/s41598-01829486-4.

Schalinski, I., Teicher, M. H., Nischk, D., Hinderer, E., Müller, O., \& Rockstroh, B. (2016). Type and timing of adverse childhood experiences differentially affect severity of PTSD, dissociative and depressive symptoms in adult inpatients. BMC Psychiatry, 16(1), 295. https://doi.org/10.1186/s12888-016-1004-5.

Scott, K. M., Smith, D. R., \& Ellis, P. M. (2010). Prospectively ascertained child maltreatment and its association with DSM-IV mental disorders in young adults. Archives of General Psychiatry, 67, 712-719. https://doi.org/10.1001/archgenpsychiatry.2010.71.

Siegfried, Z., \& Simon, I. (2010). DNA methylation and gene expression. Wiley Interdisciplinary Reviews: Systems Biology and Medicine, 2(3), 362-371. https://doi.org/ 10.1002/wsbm.64.

Simons, R. L., Lei, M. K., Beach, S. R. H., Philibert, R. A., Cutrona, C. E., Gibbons, F. X., et al. (2016). Economic hardship and biological weathering: The epigenetics of aging in a U.S. sample of black women. Social Science and Medicine, 150, 192-200. https://doi.org/ 10.1016/j.socscimed.2015.12.001.

Simpkin, A. J., Howe, L. D., Tilling, K., Gaunt, T. R., Lyttleton, O., McArdle, W. L., et al. (2017). The epigenetic clock and physical development during childhood and adolescence: Longitudinal analysis from a UK birth cohort. International Journal of Epidemiology, 46(2), 549-558. https://doi.org/10.1093/ije/dyw307.

Suarez, A., Lahti, J., Czamara, D., Lahti-Pulkkinen, M., Knight, A. K., Girchenko, P., et al. (2018). The epigenetic clock at birth: Associations with maternal antenatal depression and child psychiatric problems. Journal of the American Academy of Child and Adolescent Psychiatry, 57(5), 321-328.e2. https://doi.org/10.1016/j.jaac.2018.02.011.

Sumner, J. A., Colich, N. L., Uddin, M., Armstrong, D., \& McLaughlin, K. A. (2019). Early experiences of threat, but not deprivation, are associated with accelerated biological aging in children and adolescents. Biological Psychiatry, 85(3), 268-278. https://doi. org/10.1016/j.biopsych.2018.09.008. 
Teicher, M. H., \& Samson, J. A. (2013). Childhood maltreatment and psychopathology: A case for ecophenotypic variants as clinically and neurobiologically distinct subtypes. The American Journal of Psychiatry, 170(10), 1114-1133. https://doi.org/10.1176/appi. ajp.2013.12070957.

Vachon, D. D., Krueger, R. F., Rogosch, F. A., \& Cicchetti, D. (2015). Assessment of the harmful psychiatric and behavioral effects of different forms of child maltreatment. JAMA Psychiatry, 72(11), 1135-1142. https://doi.org/10.1001/jamapsychiatry.2015.1792.

Wolf, E. J., Maniates, H., Nugent, N., Maihofer, A. X., Armstrong, D., Ratanatharathorn, A., et al. (2018). Traumatic stress and accelerated DNA methylation age: A meta-analysis. Psychoneuroendocrinology, 92, 123-134. https://doi.org/10.1016/j. psyneuen.2017.12.007 (November 2017).

Zannas, A. S., Arloth, J., Carrillo-Roa, T., Iurato, S., Röh, S., Ressler, K. J., et al. (2015). Lifetime stress accelerates epigenetic aging in an urban, African American cohort: Relevance of glucocorticoid signaling. Genome Biology, 16(1), 1-12. https://doi.org/ 10.1186/s13059-015-0828-5.

Zannas, A. S., Jia, M., Hafner, K., Baumert, J., Wiechmann, T., Pape, J. C., et al. (2019). Epigenetic upregulation of FKBP5 by aging and stress contributes to NF- $\mathrm{KB}$-driven inflammation and cardiovascular risk. Proceedings of the National Academy of Sciences of the United States of America, 116(23), 11370-11379. https://doi.org/10.1073/pnas.. 1816847116. 